\title{
MĖGINIMAS 1919 M. PAVASARI ATSIIMTI IŠ BOLŠEVIKŲ VILNIŲ
}

\author{
doc. V Lesčius
}

Nors apie kovas su pirmuoju 1918 m. pabaigoje įsiveržusiu į Lietuvą ir iki $1919 \mathrm{~m}$. vasario pradžios užgrobusiu apie du trečdalius jos teritorijos priešu - bolševikais -jau nemažai rašyta („Karyje", „Karo archyve", „Mūsų žinyne", „Karde" ir kt. leidiniuose), tačiau daugeliu atveju atskiri kariniai veiksmai ar karinès vadovybès sumanymai apibūdinti tik fragmentiškai, tad juos reikia analizuoti išsamiau.

Šio straipsnio tikslas yra, remiantis archyvine medžiaga, vyriausybiniais dokumentais, periodine spauda, atsiminimais bei kitais šaltiniais, supažindinti skaitytojus su Lietuvos civilinès ir karinès vadovybès 1919 m. pavasari vykdyta pirmaja planinga puolamaja karine operacija, mėginant išvaduoti iš bolševikų tų metų sausio 5 dieną užimtą Lietuvos sostinę Vilnių.

1919 m. vasario-kovo mėnesiais besikurianti Lietuvos kariuomenè Kèdainių-Jonavos-Kaišiadorių-Jiezno-Alytaus baruose bei Žemaitijoje isstengè ne tik sustabdyti bolševikų veržimąsi i krašto gilumą, bet ir toliau sẻkmingai vykdè nedidelius, dažniausiai vadinamojo „ekspedicinio" pobūdžio, puldinèjimus. Jų metu issitikinta, jog daug gausesnès ir geriau ginkluotos bolševiku pajègos nèra nenugalimos, tik reikia norèti, tinkamai vadovauti ir mokèti kautis.

Po nepavykusio puolimo supamuoju manevru užimti Kauną iš šiaurès ir pietu ir taip sugriauti Lietuvos valstybės kuriamaji darbą, bolševiku vadovybe $1919 \mathrm{~m}$. vasario $24 \mathrm{~d}$. isakè propagandiniais tikslais pavadintai Lietuviškajai (buv. Pskovo) divizijai: a) įsitvirtinti linijoje Panevěžys-ŠètaŽashai-Aukštadvaris-Daugai-Marcinkonys; b) susidarius palankioms aplinkybėms, priešakinèms ir žvalgomosioms divizijos dalims slinkti TilžèsKauno-Alytaus ir Merkinès kryptimis; c) pasirengti Vilniaus-Lentvario 
gynybai; d) ypatingą dèmesi skirti dešiniajam sparnui ir užtikrinti Panevėžio rajone buvusios Latvių divizijos saugumą, palaikant su glaudžius ryšius ${ }^{1}$.

Kaip matyti, divizijai buvo iškeltas jau nebe tiek puolimų, kiek gynimosi uždavinys. Faktiškai divizija ir traukèsi iš lèto atgal. Tuo metu bolševikams pradejo nebesisekti ir kovose su lenkais - beveik visame fronte jie buvo priversti trauktis. Lenkai pradejo juos spausti ir Vilniaus kryptimi.

Jau $1919 \mathrm{~m}$. vasario viduryje Lietuvos vadovybei buvo žinoma, jog bolševikų užimtose srityse vyrauja netvarka: kariai demoralizuoti, nenori kariauti, maištauja, trūksta maisto bei kitu būtiniausių reikmenų, dalis vilniečių badauja, tarp jų siaučia i̇vairios ligos, gyventojai nepatenkinti bolševikų įvesta tvarka, didelèmis rekvizicijomis ir laukia ateinant lietuviu ar lenkų.

Lietuvos civilinè valdžia bei karinè vadovybè negalèjo likti abejinga tokiai susidariusiai padecciai. Kilo sumanymas pamėginti iš bolševiku atsiimti Vilnių. Jau $1919 \mathrm{~m}$. vasario $28 \mathrm{~d}$. krašto apsaugos ministras karin. M. Velykis issakè karin. K. Škirpai, dar 1918 m. pabaigoje ejusiam Vilniaus miesto komendanto pareigas ir gerai žinančiam bendrą tuometinę padètị mieste, parengti sostinès valdymo planą ją išlaisvinus iš bolševiku okupacijos. Karin. K. Škirpa, ir anksčiau kariuomenès vadovybei teikęs ivairiu siūlymų dèl ginkluotuju pajègų organizavimo, visu pirma patarè atsižvelgti i tai, jog, pirma, daugelis mieste gyvenusiu ivairiu tautybiu žmonių buvo skirtingos politinès orientacijos ir siekè savų tikslų; antra, jame jau buvo gerokai issitvirtinę vietiniai bei iš Sovietų Rusijos atsiųsti bolševikai bei visokie agentai. Jo nuomone, labai sunki miesto gyventoju materialinè padètis, badas bei ligos pareikalautu iš naujosios valdžios energingų ir efektyviu priemonių. Todėl, karin. K. Škirpos nuomone, reikètų skubiai susirūpinti būsimojo valdžios aparato sudarymu Vilniuje: parinkti tinkamus ịstaigu vadovus, parengti aiškias tu įstaigu veiklos instrukcijas, nubrèžti ju funkcijas, ryšius su miesto gyventojais. Kadangi mieste buvo susidariusi kritinè padėtis gyventoju materialinio aprūpinimo bei sveikatos apsaugos srityje, siūlè nedelsiant pasirūpinti maisto atsargu, numatyti efektyvią medicinos pagalbą. K. Škirpos nuomone, šios priemonès iškart pakeltų naujosios valdžios autoritetą miesto visuome-

${ }^{1}$ F. Baltušis-Žemaitis, Karas su bolševikais Lietuvoje 1919 m., Mūsu žinynas, t. 17, K, 1929, p. 287. 
nès akyse ir padètu igyti jos pasitikèjimą. Visiems svarbiausiems klausimams spręsti siūlè iš ivvairiu ministerijų atstovų sudaryti specialią komisija, kurioje dalyvautų ir karin. K. Škirpa arba bent jau būtų informuojamas apie numatytas priemones ir jų vykdymą. Gavęs iš minètos komisijos būtiną medžiagą, karin. K. Škirpa imtųi reikalingų karinių dalių, kuriomis pasiremdama Vilniaus miesto valdžia galètų vykdyti savo funkcijas, formavimo ${ }^{2}$

Karin. K. Škirpos nuomone, Vilniaus miesto saugumui užtikrinti reikalingos tokios jègos: du pėstininkų batalionai, du husarų eskadronai, kulkosvaidininkų komanda su 2 sunkiaisiais automobiliais, 300 karo policininkų, 50 raitų karinių žandarų, viena lengvosios artilerijos baterija ir vienas šarvuotas automobilis ${ }^{3}$.

Karin. K. Škirpa teigè, jog šis kariuomenès kontingentas su kitomis ginkluotuju pajègų dalimis turètu dalyvauti Vilniaus miesto užèmimo operacijoje. Be to, projekto autorius siūlè, užèmus Vilnių, iškart jame paskelbti apgulos padèti, nes mieste iš pradžių liktų nemaža bolševikų arba specialiai papirktų agentų, kurie stengtųsi visaip trukdyti miesto valdžios darbą. Apgulos padètis, jo nuomone, turètu trukti apie porą savaičių, o tuo metu būtu galima padaryti visko, ko reikia miestui išvalyti nuo priešiškų elementų. Vèliau kurį laiką galètų būti pakelbta karo padètis. Paděčiai mieste patikslinti karin. K. Škirpa dar siūlè pasiųsti specialius žvalgus ${ }^{4}$. To meto sąlygomis tai buvo gana apgalvotas, konkretus ir detalus miesto, numatyto valdyti po jo išlaisvinimo iš bolševikų okupacijos, planas.

Dar kovo pradžioje krašto vadovybę pasiekė žinios apie lenkų jëgų koncentravimą Gardino apylinkèse. Netrukus didelès, gerai ginkluotos jų kariuomenès dalys ėmè smarkiai pulti bolševikus Rytų Lietuvoje ir stumti iš šio krašto. Puldami bolševikus jie savo kariuomenès kairiuoju sparnu užkliuvo už Lietuvos rytinių etninių sienų ir ėmé skverbtis i jos teritoriją Vilniaus kryptimi.

1919 m. vasario-kovo mėnesiais lietuvių kariuomenė buvo skubiai organizuojama bei rengiama ir gerokai sustiprejjo. Buvo isteigta naujų

\footnotetext{
${ }^{2}$ Karin. K. Škirpos 1919 m. vasario 28 d. slaptas pareiškimas Nr. 8 Krašto apsaugos ministrui, $L C V A$, f. 923, ap. 1, b. 149, 1. 216.

${ }^{3}$ Ten pat, 1. 217.

${ }^{4}$ Ten pat.
} 
kariuomenès dalių, vyko reguliarus jų mokymas. Gauti ginklai ir apranga pakèlè karininkų bei kareivių kovinę dvasią. Pamažu tobulëjo ir pati kariuomenès organizacija.

Nors kariuomenès pajėgumas dar buvo nedidelis, Lietuvos vyriausybè, pasitarusi su kariuomenès vadovybe, nutarè pasinaudoti patogiu momentu, pulti bolševikus ir pirmiesiems atgauti sostinę Vilnių. Šiam uždaviniui įvykdyti nutarta sudaryti Atskirają brigai, kurios viršininku 1919 m. kovo 11 d. buvo paskirtas karin. S. Nastopka, o jos štabo viršininku - karin. B. Giedraitis ${ }^{5}$.

Dar neturint pakankamai jègų pulti bolševikus visu frontu, karinė vadovybe nutare sutelkti savo pajègas dviejose vietose ir suduoti priešui smūgi, kuris priverstų ji trauktis.

Vykdant krašto apsaugos ministro karin. A. Merkio 1919 m. kovo 24 d. Vilniaus grupei paskelbtą slaptaji isakymą Nr. 1, bolševikams pulti buvo sudarytos 2 rinktinès: Dešinioji pietine - iš Alytaus igulos ir Kairioji šiaurinè - iš Kauno igulos 6 .

Dešiniają rinktinę sudare I pėst. pulko keturios kuopos, raituju žvalgu komanda (apie 30 raitelių), 8 sunkieji kulkosvaidžiai ir karin. M. Pečiulionio vadovaujamas artilerijos būrys ( 2 patrankos). Rinktinès vadas - karin. K. Ladyga. Jos uždavinys buvo kovo 28 d. išžygiuoti iš Alytaus, toliau pulti ir užimti Daugus, Varènos bei Valkininku miestelius ir geležinkelio stotis, o po to žygiuoti Vilniaus kryptimi

Kairiojoje rinktineje buvo II pèst. pulko I batalionas ir IX kuopa (apie 900 žmoniu), Atskiras batalionas (vadas - karin. K. Škirpa), kuriame buvo keturios kuopos, karo žandarų, kulkosvaidžių, raitujų žvalgų komandos (iš viso apie 500 žmoniu). Rinktinei dar buvo paskirtas karin. Pr. Uoginto vadovaujamas artilerijos būrys (2 patrankos) ir II husaru eskadronas. Iš viso rinktineje buvo apie 1400 karių. Jai vadovavo II pèst. pulko I bataliono vadas karin. J. Butkus. Ši rinktine turejo išvykti iš Kauno kovo $27 \mathrm{~d}$. ir po poros dienu pulti priešą plentu Žiežmariai-Vievis-Vilnius

Aviacijos daliai įsakyta stebėti judejjimą priešo užnugaryje. Inžinerijos daliai, rinktinèms pasistūmèjus i priekị, sutaisyti geležinkelio linija

\footnotetext{
${ }^{5} 1919$ m. issakymai Krašto apsaugos ministerijai, $L C V A$, f. 384, ap. 1, b. 3, 1. 47.

${ }^{6}$ Atskiros brigados ir II pėst. divizijos štabo karo dienynas (1919 03 11-1919 12 31), LCVA, f. 929, ap. 3, b. 76, 1. 2-3.

${ }^{7}$ Krašto apsaugos ministro karin. A. Merkio slaptas įsakymas Nr. 1 Vilniaus grupei, $L C V A$, f. 1 , ap. 1, b. $15,1.42-43$.

${ }^{8}$ Ten pat; A. V. Kautynès ties Žasliais ir Strošiūnais, Karys, K, 1939, Nr. 14, p. 441.
} 
Kaišiadorys-Lentvaris. Kadangi vieną rinktinę nuo kitos skyrè daugiau kaip $50 \mathrm{~km}$ atstumas, susisiekimo dalies viršininkui isakyta paskirti po vieną motociklą kiekvienai rinktinei ryšiui su brigados štabu palaikyti. Rinktinių viršininkai turèjo tam tikrą skaičių telefonistų siųsti $\mathfrak{i}$ artimiausias telefono stotis - Alytų, Daugus, Žiežmarius ir Rumšiškes, kad iš ten perduotu žinias Krašto apsaugos ministerijos štabui ${ }^{9}$.

Kadangi Kairioji rinktinè dèl organizacinių nesklandumų nurodytu laiku iš Kauno išvykti dar negalejo, kovo $27 \mathrm{~d}$. jai buvo isakyta tai padaryti kovo 31 d., o Dešiniajai rinktinei išvykti iš Alytaus balandžio 1 d. Buvo patikslinta, jog Dešinioji rinktinè, užèmusi Valkininkus, žygiuotu Vilniaus kryptimi palei geležinkeli Varẻna-Lentvaris. Kiekvienas kareivis privalèjo turèti ne mažiau kaip 350 šovinių: 90 su savimi ir 260 rezervo. Vienam kulkosvaidžiui turejjo būti skirta 4000 šovinių. Maistu ir pašaru reikejo apsirūpinti 6 dienoms. Dešiniajai rinktinei maisto bazé buvo numatyta Varenoje, o Kairiajai - Žasliuose. Sanitarijos dalies viršininkas privalëjo pasirūpinti sužeistų ir susirgusių karių evakuacijai. ${ }^{10}$

Taigi abiem rinktinèms uždaviniai buvo keliami tie patys, šiek tiek skyrèsi tik jų vykdymo laikas.

1919 m. kovo pabaigoje bolševikai šiame fronto bare buvo užèmę poziciją Nedzingè-Daugai-Pivašiūnai-Dusmenys-Onuškis-AukštadvarisZasliai. Daugų-Varènos-Valkininkų krypti i Vilnių saugojo Lietuviškosios (Pskovo) divizijos III ir IV šaulių pulkai, o Trakų-Vilniaus krypti - tos pat divizijos V, VI, ir VII pulkų šauliai. Daugiausia bolševiku jëgų buvo sutelkta prie pagrindiniu kelių einančiu i Vilnių. Bolševikų pajègos buvo papildytos žmonèmis, ginklais ir šaudmenimis, tačiau jų moralè buvo smukusi.

Tuo tarpu abiejose lietuvių rinktinèse vyko paskutinieji pasiruošimo pulti bolševikus darbai. Balandžio $2 \mathrm{~d}$. prie Alytuje veikusio I pėst. pulko II bataliono prisijungè iš Marijampolès atvykęs pulko štabas su I batalionu, kuri sudare 19 karininku, 364 kareiviai, artilerijos baterija su 2 karininkais bei 79 kareiviai ir husarų eskadronas ${ }^{11}$.

Atskirosios brigados vadas karin. S. Nastopka 1919 m. balandžio $1 \mathrm{~d}$. papildomai nurodè I pèst. pulko vadui karin. K. Ladygai neparengtus ir blogai aprengtus bei aprūpintus kareivius palikti Alytuje, o su visais kitais

\footnotetext{
${ }^{9}$ Atskiros brigados ir II pèst. divizijos štabo karo dienynas, $L C V A$, f. 929, ap. 3, b. 76, 1. 3.

${ }^{10} 1919$ m. kovo 27 d. isakymas Nr. 2 Vilniaus grupei, LCVA, f. 1, ap. 1, b. 15, 1. 41.

${ }^{11} 1919$ m. isakymai I pesst. pulkui, $L C V A$, f. 513, ap. 1, b. 1, 1. 150.
} 
balandžio $3 \mathrm{~d}$. pradèti vykdyti isakymą Nr. 1 Vilniaus grupei, prieš tai išsiuntus gerą žvalgybą Varènos-Valkininkų kryptimi ${ }^{12}$.

Dešiniosios rinktinès veiksmai. $1919 \mathrm{~m}$. balandžio $3 \mathrm{~d}$. apie 15 vai. Dešinioji rinktinè pradejjo žygi iš Alytaus Daugu kryptimi. Iki tos pat dienos vakaro ji atkovojo Pavartėnu, Viečiūnų, Pocilonių, Bogužiškių, Naujaplenčio, Švobiškiu kaimus ir Bogužiškiu dvarą. Prie Pociloniu kaimo rinktinè buvo padalinta i dvi voras - pagrindinę ir šalutinę. Šalutinė vora (VII kuopa su 2 sunkiaisiais kulkosvaidžiais ir raitujų žvalgų komanda - 20 žmonių) turèjo žygiuoti pietų kryptimi i Arčiūnų kaimą. Iš čia žvalgai turejo išsiaiškinti priešo padèț Biniūnų-Kazimieriškių kaimu apylinkèse, o VII kuopa, vadovaujama karin. M. Réklaičio - pulti Daugu ežero pietinę pusę ir toliau žygiuoti Geidukoniu kaimo kryptimi ${ }^{13}$.

Tuo tarpu rinktinès pagrindinè vora toliau puolè plentu Varènos kryptimi. Balandžio 4 d. 3 vai. I ir II kuopos atkovojo vakarus nuo Daugu buvusią 198 aukštumą. Artilerija išsidèste i vakarus nuo šios aukštumos palei plentą Alytus-Daugai, netoli Pocilonių kaimo. I šonus nuo pagrindinès voros pasiusti žvalgai netoli Daugu 4 vai. susišaude su bolševikais. Tada artilerijos baterija atidengè ugni $\mathfrak{i}$ šiaurinę Daugų miestelio dali. I pagalbą iš Alytaus atvykusios dvi vokiečiu baterijos taip pat apšaudè bolševiku pozicijas. Nors bolševikai ir smarkiai priešinosi, bet rinktinès I ir II kuopos, sutelkusios smarkią ugni, 6 vai. 30 min. užèmė Daugus. Bolševikai skubiai pasitraukè. I kuopa ižengè i Daugus be nuostolių, o II kuopos vienas kareivis buvo užmuštas, kitas sužeistas ${ }^{14}$ (žr. schema Nr. 1).

Užėmus i Daugus vora nužygiavo Bobriškių kaimo kryptimi. I ir II kuopos, puldamos prieša, po trumpo susišaudymo susigrą̌zino Doškoniu ir Verikantonių kaimus. Voros avangardinès dalys toliau žygiavo priekyje, iš paskos sekė vokiečių, o už jų - lietuvių artilerijos baterijos. Pačiame gale žygiavo pulko rezervas (II bataliono dvi kuopos), išsiuntęs i šonus apsaugą. Prie Vèžioniu kaimo bolševikai i žygiuojančią vorą atidengė smarkią kulkosvaidžiu ir šautuvų ugni. Voros priekyje žygiavusios kuopos išsiskleidè grandinèn, o tuo tarpu vokiečių artilerija apšaudè apkasuose

\footnotetext{
${ }^{12}$ Atskiros brigados vado karin. S. Nastopkos 19190401 pranešimas Nr. 19 I pėst. pulko vadui

karin. K. Ladygai, LCVA, f. 929, ap. 3, b. 90, 1. 60.

${ }^{13}$ I pėst. pulko veikimo prieš didžiumiečius linkui Daugų, Bobriškių, Varènos ir Valkininkų

1919 m. balandžio 4-5 d. reliacija, LCVA, f. 929, ap. 3, b. 3, 1. 109.

${ }^{14}$ Ten pat.
} 


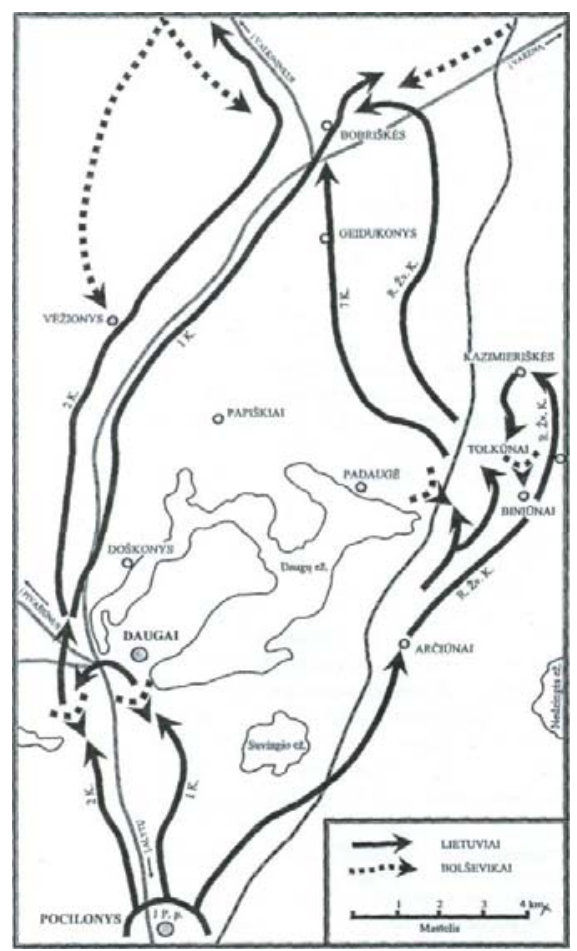

Schema Nr. 1

Daugu kautynès 1919 m. balandžio 3-5 d.

86 
Isitvirtinusius bolševikus. Šie buvo priversti su nuostoliais pasitraukti. Vokiečių karininkai automobiliuose įrengtų kulkosvaidžių ugnimi persekiojo bėganti priešą o jiems ịkandin sparčiai veržèsi i priekị lietuvių pèstininkai ${ }^{15}$

Atkovojus Geidukoniu ir Kirklioniu kaimus, pastebèta bolševiku gurguolè, kurios dalis nuo Bobriškiu kaimo trauke i Valkininkus, o dalis plentu i Varèną. Péstininkams bei lietuvių ir vokiečiu artilerijai apšaudžius pasitraukiančią priešo gurguolę, voros priešakinès dalys užèmé Bobriškių-Valkininkų kelio tiltą, kuris buvo greitai sutaisytas, nes bolševikai ji buvo šiek tiek apgadinę. Netrukus II kuopa susigrąžino Aleksandravos ir Vazgirdoniu kaimus, o I kuopa - Bobriškes. Atgavus šias vietoves, vokiečiai pareiškè, jog toliau jie nebežygiuosią, nes to daryti neleidžianti jų vadovybè, ir sugrižo i Alytų ${ }^{16}$.

Rinktinès vadas karin. K.Ladyga, neturèdamas žiniu iš šalutinès voros (VII kuopos ir raituju žvalgu komandos), išvykusios iš Pavartenu kaimo bei Bogušiškių dvaro ir turejusios žygiuoti i prieki palei pietinę Daugų ežero pusę per Rimènus, Padaugę bei Gūdžius Geidukonių kaimo kryptimi, savo padejjèją karin. Ig. Musteiki su II kuopa ir 2 kulkosvaidžiais paliko Vazgirdonių kaime ir i Puodžių kaimą pasiuntė žvalgybą. I kuopa užèmė poziciją prie Bobriškių-Varenos plento buvusiose 128 ir 131 aukštumose. Rinktinès rezervas apsistojo Bobriškèse.

Nors puolimas buvo sustabdytas, tačiau artilerijos baterija, užėmusi pozicija pamiškèje prie plento i rytus nuo Bobriškių, apšaudè Varènoje buvusias bolševikų stovyklas. Bolševikai atsake tuo pačiu. Apie 17 vai. ju dalinys, remiamas artilerijos, iš Ežerieku ir Druckūnų kaimu ėmè veržtis i prieki, grasindamas dešiniajam rinktinès šonui. Rinktinè buvo priversta pasitraukti i vakarus nuo Bobriškiu i 138 ir 140 aukštumas. Karin. I Musteikiui buvo įsakyta su II kuopa pasitraukti iš Vazgirdoniu i ̇ Aleksandravos kaimą. Rinktinei traukiantis toliau, jis turejo per Pavarènio kaimą pasiekti Pamusiu dvarą, pereiti per Varènès tiltą ir susijungti su pulku prie Vèžioniu kaimo. Atejjus vakarui, rinktinè apsistojo GeidukoniuKirklionių kaimų linijoje ${ }^{17}$.

\footnotetext{
${ }^{15}$ Lietuvos kariuomenès kūrimosi ir pirmosios mūsų kariuomenès operacijos 1919 m., LCVA, f. 929 , ap. 3 , b. $4,1.32$.

${ }^{16}$ I pèst. pulko veikimo prieš didžiumiečius..., $L C V A$, f. 929, ap. 3, b. 37, 1.109.

${ }^{17}$ Ten pat, b. $3,1.109$.
} 
Tuo tarpu VII kuopa, visą laiką žygiavusi i prieki anksčiau nurodytomis vietovèmis, ties Padaugès kaimu susirèmè su bolševikais, kurie i kuopą atidengè smarkią 2 kulkosvaidžių ugni. Traukdamiesi bolševikai atkakliai pasipriešino ir ties Gūdžių kaimu, tačiau, neatlaikę VII kuopos puolimo, pasitraukè. Atkovojusi minètas vietoves, VII kuopa apie 22 val. atvyko į Geidukonis. Jos nuostoliai - 2 sužeisti kareiviai. ${ }^{18}$

Raitujų žvalgų komanda, su bolševikais susirèmusi ties Marcinavos vienkiemiu, o po to prie Bobriškių, su pulku susijungè apie 21 vai. 50 min. Jos nuostoliai - 1 raitelis užmuštas ir 2 sužeisti. Karin. Ig. Musteikis su II kuopa, perėjęs per Varėnès upės tiltą ties Pamusės dvaru, su pulku susivienijo balandžio 5 d. 2 vai. nakties. Kuopa nuostolių neturējo. Kadangi bolševikai intensyviai apšaude rinktinę iš dešiniojo ir kairiojo šonu ir, vietinių gyventojų pranešimu, ruošėsi ją pulti, pulkas užėmè geresnę poziciją Vèžionių-Gudžiu kaimų linijoje ${ }^{19}$.

Balandžio $5 \mathrm{~d}$. buvo skirta poilsiui, o 19 vai. pulkas turejjo žygiuoti i prieki ir atsiimti Bobriškes. Tačiau 13 vai. 22 min. iš kariuomenès vadovybès buvo gauta telefonograma karinę operaciją sustabdyti. Buvo sužinota, jog bolševikai, sutelkę didesnes jègas, nuo Vaikantonių ir Daškonių kaimu pusès grasina kairiajam voros sparnui. Karin. K. Ladyga ịsake pulkui pasitraukti atgal. Iš kairiojo sparno puolantieji bolševikai, apšaudyti šautuvų ir artilerijos ugnimi, išbejgiojo. Pulkas pasitraukẻ tvarkingai. 20 vai. 50 min. jis buvo Dauguose ir pernakvojo Viečiūnu-Pocilonių linijoje. Balandžio 6 d. 9 vai. I pèst. pulkas sugrižo į Alytų ${ }^{20}$. Čia jis toliau tvarkėsi, mokėsi, ruošèsi naujoms kovoms ir toliau veikdamas Atskirosios brigados sudètyje $\mathrm{e}^{21}$.

Kairiosios rinktinės veiksmai. Krašto apsaugos ministro įsakymu Nr. 1 Vilniaus grupei Kairiosios (šiaurinès) rinktinès vadas karin. J. Butkus 1919 m. kovo 31 d. su rinktinès dalimi - II pést. pulko I batalionu bei IX kuopa, artilerijos II baterijos I būriu ir puse husarų eskadrono - iš Kauno išžygiavo Vilniaus kryptimi. Šias karines dalis Kaune karin. J. Butkus perèmè tik išvykdamas i kautynes, todèl nebuvo susipažinęs nei su

\footnotetext{
${ }^{18}$ Ten pat, 1. 109-110.

${ }^{19}$ Ten pat, 1.110.

${ }^{20}$ Ten pat.

${ }^{21} L C V A$, f. 384 , ap. 1, b. 3, 1. 58.
} 
jau paskirtais karininkais, nei su bendra padètimi minètose dalyse. Tą pačią kovo 31 d. rinktinès dalis atvyko į Rumšiškes, kur Atskirosios brigados vadas karin. S. Nastopka jai paskelbė naują ịsakymą. Šiuo ịsakymu ị rinktinès sudèti įeinąs Atskirasis batalionas turèjo likti Rumšiškèse rezerve, o II pèst. pulko I batalionas, II baterijos būrys ir I husaru eskadrono dalis balandžio 1 d. pasiekti Žiežmarius, iš kur kitą dieną pradèti puolimą ${ }^{22}$.

Atvykusi i Žiežmarių rajoną rinktinè rado vokiečių kariuomenès dalini - 19 savanoriu bataliona, kuris saugojo vokiečių ir bolševikų tarpusavyje nustatytą liniją - Kaišiadorių-Žiežmarių bara. Vokiečių pagalbos lietuviai nesitikejjo, nes tuo laiku vokiečiu kariuomenè buvo demoralizuota ir apimta revoliucinès dvasios. Taigi reikejjo pasikliauti vien savomis jëgomis. Kadangi nebuvo ištisinio fronto, bolševikai galëjo lietuviu kariuomenę pulti iš sparnų, todèl į Žaslius ir Aukštadvarị buvo pasiųsti raiteliai. Rinktinès vadovybè neturejjo telefono ryšio nè su vienu daliniu. Nors iš štabo ir buvo atsiųsta telefonistu grupé, tačiau jie neturejo nẻ vieno telefono aparato. Ryši teko palaikyti tik per pasiuntiniu.

Bolševikai buvo ịsitvirtinę Strošiūnų-Pajautiškių-Guronių-Žasliu geležinkelio stoties ir Žaslių miestelio linijoje. Jų jègos buvo daug didesnès negu lietuvių. Prieš lietuvius veikè bolševikų Lietuviškosios (Pskovo) divizijos I, II ir VI šaulių pulkai. Lietuvių rinktinès vadovybė manė, jog bolševikai nežino apie rinktinès atvykimą i Žiežmarius ir todèl tikejjosi priešą užpulti netikètai. Tačiau buvo kitaip - priešai laukẻ puolimo ${ }^{23}$.

Balandžio $2 \mathrm{~d}$. auštant II pèstininkų pulko I bataliono dalys pradèjo puolimą. Artilerija jau nuo 7 vai. ryto apšaude priešą. I kuopa turejjo Atgauti Paltininkus, Guronis ir Žaslius, II kuopa - Pajautiškes, III kuopa Strošiūnus I ir II, IX kuopa - Strèvininkus, Dirgalionius ir Liu-tonius. Atskirojo bataliono I kuopa, husarų eskadronas ir žvalgų komanda buvo rezerve ${ }^{24}$.

I kuopa (vadas - karin. A. Sinkevičius), puldama priešą minèta kryptimi, tikèjosi bolševikus užklupti Tarpumiškių dvare, tačiau čia jų neradusi mišku ir palauke žygiavo toliau. Išaušus kuopa artėjo prie Paltininku, kur buvo sutelktos stipresnès priešo jègos, o Guronyse - artilerija.

\footnotetext{
${ }^{22}$ A. Vasiliauskas, Žaslių-Daugų operacija 1919 m. balandžio 2-7 d., Karo archyvas, t. 2, K., 1940, p. 190.

${ }^{23}$ Atskiros brigados ir II pėst. divizijos štabo karo dienynas, $L C V A$, f. 929, ap. 3, b. 76, 1.6 .

${ }^{24}$ Kairiosios voros mūšių Žiežmarių-Vievio rajone reliacija, $L C V A$, f. 929 , ap. 3, b. 37, 1. 50.
} 
Pati vietovè buvo labai patogi gintis, todèl bolševiku pozicijos buvo geros. Nors I kuopą rèmè karin. Pr. Uoginto vadovaujamas artilerijos būrys, tačiau jos puolimą priešas atrèmė stipria artilerijos, kulkosvaidžių ir šautuvų ugnimi. Dauguma I kuopos kareivių kautynėse dalyvavo tik pirmą kartą, todèl tokia stipri priešo ugnis tarpe jų sukèlè sąmyši. Kuopai teko pasitraukti i Tarpumiškes ${ }^{25}$.

II kuopa (vadas - karin. K. Mackevičius) veržèsi ị Pajautiškes. Ją irgi pasitiko stipri priešo ugnis. Kuopai taip pat teko atsitraukti $\mathfrak{i}$ Tarpu miškes. Susišaudymo metu buvo sužeistas vienas kuopos kareivis. I ir II kuopos savo uždavinio neivykdè ${ }^{26}$.

III kuopa (vadas - karin. J. Kairionis) puolè vaduoti Strošiūnus, kur apsistojusi bolševikų kuopa lietuvių puolimo nesitikèjo. Todèl po trumpo susišaudymo bolševikai išbejgiojo. I ir II Strošiūnai buvo užimti. Iš priešo buvo paimta 1 kulkosvaidis, 5 šautuvai ir kt. turto ${ }^{27}$.

TX kuopa (vadas - karin. Marcinėnas), ryžtingai kovodama dèl Strejvininku̧, Dirgalionių ir Liutoniu̧, po keleto valandų mūšio juos atgavo ir issitvirtino, pastatydama 40 žmonių užtvorą. Husarų būrys, pasiųstas saugoti kairiojo rinktinès sparno, prie Kurniškių dvaro išvaikè ten buvusią negausią bolševikų sargybą ir paime iš jos 2 šautuvus, šoviniu ir nemažą ryšuli proklamacijų. Ties Kurniškiais palikę sargybą, husarai irgi pasitraukè i Tarpumiškes ${ }^{28}$.

Balandžio 2 d. puolimas nepavyko visų pirma todèl, kad nebuvo suderinti kuopų veiksmai. O tai priklausė nuo aukštesniosios vadovybės veiklos. Šio puolimo nauda buvo tik ta, jog buvo tiksliai sužinota, kaip išsidèsčiusios priešo jẻgos. Balandžio $2 \mathrm{~d}$. nepasisekus įvykdyti numatytojo uždavinio, Atskirosios brigados vadas karin. S. Nastopka nutarè rinktinès rezervą pritraukti arčiau fronto. Labai blogu oru bei klampiais keliais naktị iš balandžio 2 d. i 3 d. iš Rumšiškių i Žiežmarius atvyko Atskirasis batalionas. Čia i̇vykusiame brigados vado karin. S. Nastopkos ir batalionų vadų karin. J. Butkaus ir K. Škirpos pasitarime buvo nuspręsta balandžio 3 d. pakartoti puolimą. Jo uždavinys buvo išstumti bolševikus iš Strošiūnų-Zaslių linijos ir, susiklosčius palankioms sąlygoms, toliau veržtis Vievio-Vilniaus kryptimi ${ }^{29}$.

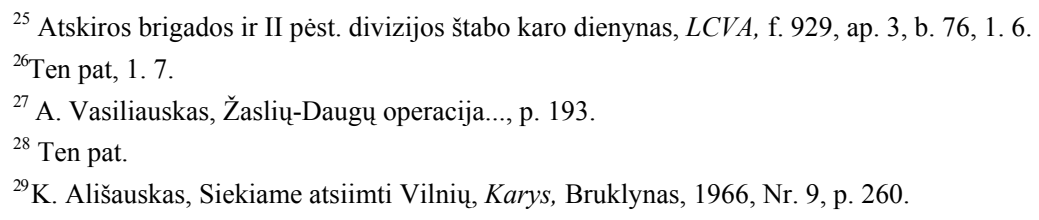


Čia buvusioms pajëgoms sustiprinti karin. S. Nastopka įsakè II pèst. pulko I bataliono barą sumažinti dešiniajame sparne iš Dirgalioniu atitraukiant IX kuopą. Ją pakeite Atskirojo bataliono kuopa. Be to, iš šio bataliono dar buvo atsiustas kulkosvaidininkų būrys ir raituju žvalgų komanda. Kitos trys Atskirojo bataliono kuopos turejo likti rezerve Žiežmariuose. Kartu buvo isakyta sustiprinti žvalgybą Aukštadvario, Kietaviškių ir Korkučionių kryptimi ${ }^{30}$.

Balandžio 3 d. rytą virš Žiežmarių pasirodè lietuvių lèktuvas, kuris, apsukęs keletą ratų apie mūsų kariuomenę, numetė pranešimą apie priešo jẻgų išsidèstymą. Mūsų aviacijos pasirodymas pakẻlẻ karių kovinę dvasią.

Apie 15-16 vai. II pèst. pulko I bataliono I ir II kuopos, išsiskleidusios grandinèmis, pasipyle iš miško ir prasiveržè Paltininkų-Guroniu kryptimi. Purvas buvo tiesiog neišbrendamas. Kai kur teko bristi per apsemtą pievą. İbridus i vandeni, bolševikai apšaudè kulkosvaidžių ugnimi nuo 150 aukštumos i pietus nuo Guronių. Grandinėms kartais teko gulti i vandeni, tačiau jos nesitrauke, bet slinko pirmyn. Pradejo smarkiai snigti. Pasinaudojusios sniego priedanga, kuopos prisiartino prie priešo apkasu ir apmètė juos granatomis. Neatlaikę puolimo, bolševikai pasitraukè. Atkovoję aukštuma, mūsiškiai apšaudè bolševikų pozicijas prie Žasliu geležinkelio stoties ${ }^{31}$.

Bolševikai vis dar laikèsi Pajautiškèse, bet, pajutę smarkų lietuviu spaudima, pasiunte savo pasiuntinius i Žaslius prašyti pagalbos. Tačiau jų pasiuntiniai pateko ị lietuvių nelaisvę. Iš rasto pranešimo, kuri pasiuntiniai siuntė savo vadovybei, sužinota, jog Pajautiškèse yra 120 bolševiku, kuriuos „baltieji" smarkiai spaudžia ir, nesulaukus paramos, teksią iš tos vietovės pasitraukti. Ši žinia lietuvius padrąsino. Karininkai A. Sinkevičius ir K. Mackevičius, palikę dali savo kuopų Guronyse, su trim būriais ir 1 kulkosvaidžiu patraukẻ Pajautiškių kryptimi. Bolševikai, pajutę, jog yra supami, spruko i pietus nuo Pajautiškių kaimo buvusi mišką. Kaimas buvo išlaisvintas be mūšio ${ }^{32}$.

Balandžio $4 \mathrm{~d}$. auštant rinktinès žvalgai buvo pasiųsti į Žaslių miesteli, o II pėstininku pulko I bataliono I kuopa - į Žasliu geležinkelio stoti. Bolševikai, pastebejję artinantis lietuvių žvalgus, paleido keletą šūvių ir skubiai paliko Žaslių miesteli pasitraukè Vievio kryptimi. Ta pačia

${ }^{30}$ A. Vasiliauskas, Žaslių-Daugų operacija..., p. 194.

31 Ten pat, p. 195.

${ }^{32}$ Kairiosios voros mūšiu Žiežmarių-Vievio rajone reliacija, $L C V A$, f. 929, ap. 3, b. 37, 1. 50. 
kryptimi pasitraukè ir bolševikai iš Žasliu geležinkelio stoties, palikę vežimą sviedinių, telefono aparatą ir vienos kuopos raštinę su antspaudais ir dokumentų blankais ${ }^{33}$.

Nors bolševikai ir buvo priversti pasitraukti iš jų užimto rajono iki pat Vievio miestelio, bet jie nebuvo sumušti. Todèl kitą dieną puolimo buvo atsisakyta ir rinktinè issitvirtino Strošiūnų-Pajautiškių-Žaslių geležinkelio stoties ir Žaslių miestelio linijoje. Rinktinè užèmẻ šią liniją tokia tvarka: II pesstininkų pulko I kuopa - už Žaslių stoties ir miestelio, II kuopa - už Pajautiškių, III kuopa - už Strošiūnų, I ir IX kuopa - už Dirgalionių ir Liutonių kaimų. Kairèje I kuopa palaikè ryši su vokiečiais, 0 dešinèje su jais susisieké IX kuopa. Atskirojo bataliono IV kuopa ir žvalgų komanda buvo rezerve už II pèstininkų pulko I ir II kuopų, to pat bataliono II kuopa - už II pėstininkų pulko III kuopos Gurkliuose, o I ir III kuopos bei II husarų eskadronas liko rezerve Žiežmariuose. Artilerija buvo užèmusi poziciją prie Tarpumiškiu palivarko. Tuo tarpu I husarų eskadronas tiek kautynių metu, tiek ir joms pasibaigus atidžiai stebejjo priešo veiksmus Aukštadvario apylinkèse ${ }^{34}$.

Po pasisekusių balandžio 3 d. kautynių rinktinè galëjo žygiuoti pirmyn ir pasiekti Vievi. Tačiau ji nei kairèje, nei dešinèje neturèjo ją remiančiu kariniu pajègų, todèl veržtis i priekị buvo rizikinga, nes grèsė pavojus iš abiejų sparnu būti priešo apsuptai ir sunaikintai. Atsižvelgiant i tai, vyko tik mūsų žvalgų susirèmimai su bolševikų sargybomis. Balandžio 5 d. II husarų eskadronas atkovojo Jagielonių kaimą, o balandžio 6 d. - Semeliškes. Visų aukščiau minètų mūšių metu iš priešo buvo paimtas 1 kulkosvaidis, 3 lauko virtuvès, 4 dviračiai vežimai šoviniams, 6 telefono aparatai, daug telefono kabelio, 2 vežimai, 4 arkliai ir apie 50 belaisviu. Netoli Vievio buvo paimtas intendantūros sandèlis, iš kurio pavyko viską išsivežti. Mūsų nuostoliai - 3 užmušti ir 25 sužeisti kareiviai ${ }^{35}$.

Po šiu kautynių bolševikai, sužinoję, jog lietuviu jẻgos šiame bare yra daug menkesnès ir, be to, vokiečiai jiems nepadeda, ruošèsi lietuvius

30 A. Vasiliauskas, Žaslių-Daugų operacija..., p. 194. " ${ }^{31}$ Ten pat, p. 195.

${ }^{32}$ Kairiosios voros mūšių Žiežmarių-Vievio rajone reliacija, $L C V A$, f. 929, ap. 3, b. 37, 1. 50.

${ }^{33}$ Atskiros brigados ir II pėst. divizijos štabo karo dienynas, $L C V A$, f. 929, ap. 3, b. 76, 1.7.

${ }^{34}$ Kairiosios voros mūšių Žiežmarių-Vievio rajone reliacija, $L C V A$, f. 929, ap. 3, b. 37, 1. 50.

${ }^{35}$ Atskiros brigados ir II pėst. divizijos štabo karo dienynas, $L C V A$, f. 929 , ap. 3, b. 76, 1. 8.92 
pulti. Jau balandžio 6 d. lietuviai turèjo žinių, jog Žaslių bare priešas telkia didesnes jègas. Balandžio $7 \mathrm{~d}$. vakare buvo pastebètas jų intensyvus judejjimas. Rinktinè pasiruošè gintis, budèjimas pozicijose buvo sustiprintas, rezervinès kuopos įspètos būti pasiruošusius.

Balandžio $8 \mathrm{~d}$. anksti rytą tirštos priešo grandinès pradejo smarku puolimą Žaslių-Strošiūnų bare. Šiuos du punktus skyrè tankus miškas, išraižytas grioviais ir net kalnagūbriais, todèl kautynių metu tarp veikiančių dalių buvo sunku palaikyti ryši. Nors telefonų jau turèta, bet jie blogai veikè. Kautynių metu Žiežmarių-Strošiūnų telefono linija visiškai nustojo veikusi, todèl kuopu vadams teko veikti savarankiškai ir rodyti daug iniciatyvos ${ }^{36}$ (̌rr. schema Nr. 2).

Kairiajame sparne (Žasliai-Pajautiškès) barą gynè II pėstininkų pulko I ir II kuopos, Atskirojo bataliono žvalgų komanda (apie 30 vyru) bei IV kuopa, kurioje buvo taip pat ne daugiau kaip 50 vyru. Śioms pajègoms vadovavo karin. K. Škirpa. Bolševikai ypač smarkiai puolè Žaslių geležinkelio stotị ir Talpūnus, o Pajautiškes mėgino apsupti mišku iš pietų pusès ir suduoti smūgị iš sparno. Tačiau II pėstininkų pulko II kuopa sulaikė priešo puolimą ir priverte ji trauktis atgal mišku i rytus. Karin. K. Škirpa, gavęs pranešima, jog II pèst. pulko III kuopa, bolševikų smarkiai spaudžiama ties Strošiūnais, nepajègia atsilaikyti, vos prasidèjus mūšiui pasiuntė jai i pagalbą karin. A. Jakšto vadovaujamą Atskirojo bataliono II kuopą. Be to, žinodamas apie dar menką šio bataliono pasirengimą kovoms, karin. K. Škirpa iš turèto rezervo nukreipe i Strošiūnus nusiuntė ir to pat bataliono IV kuopą. Priešas buvo kontratakuotas ir durtuvu kautynèse priverstas pasitraukti i Mijaugonių kaimą. Žvalgu komanda buvo pasiųsta palaikyti ryšio tarp Pajautiškių ir Strošiūnus ${ }^{37}$.

Tuo tarpu bolševikai, panaudoję smarkią artilerijos ir kulkosvaidžių ugni, toliau didelèmis jẻgomis puolè karin. K. Škirpos vadovaujamą bara, ypač jo kairiji sparną. Jị gynusi II pėst. pulko I kuopa, neatlaikiusi puolimo, apie 17 vai. pasitraukè iš Žaslių stoties ir miestelio ${ }^{38}$.

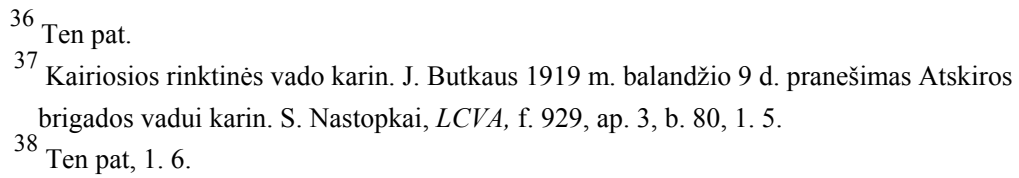




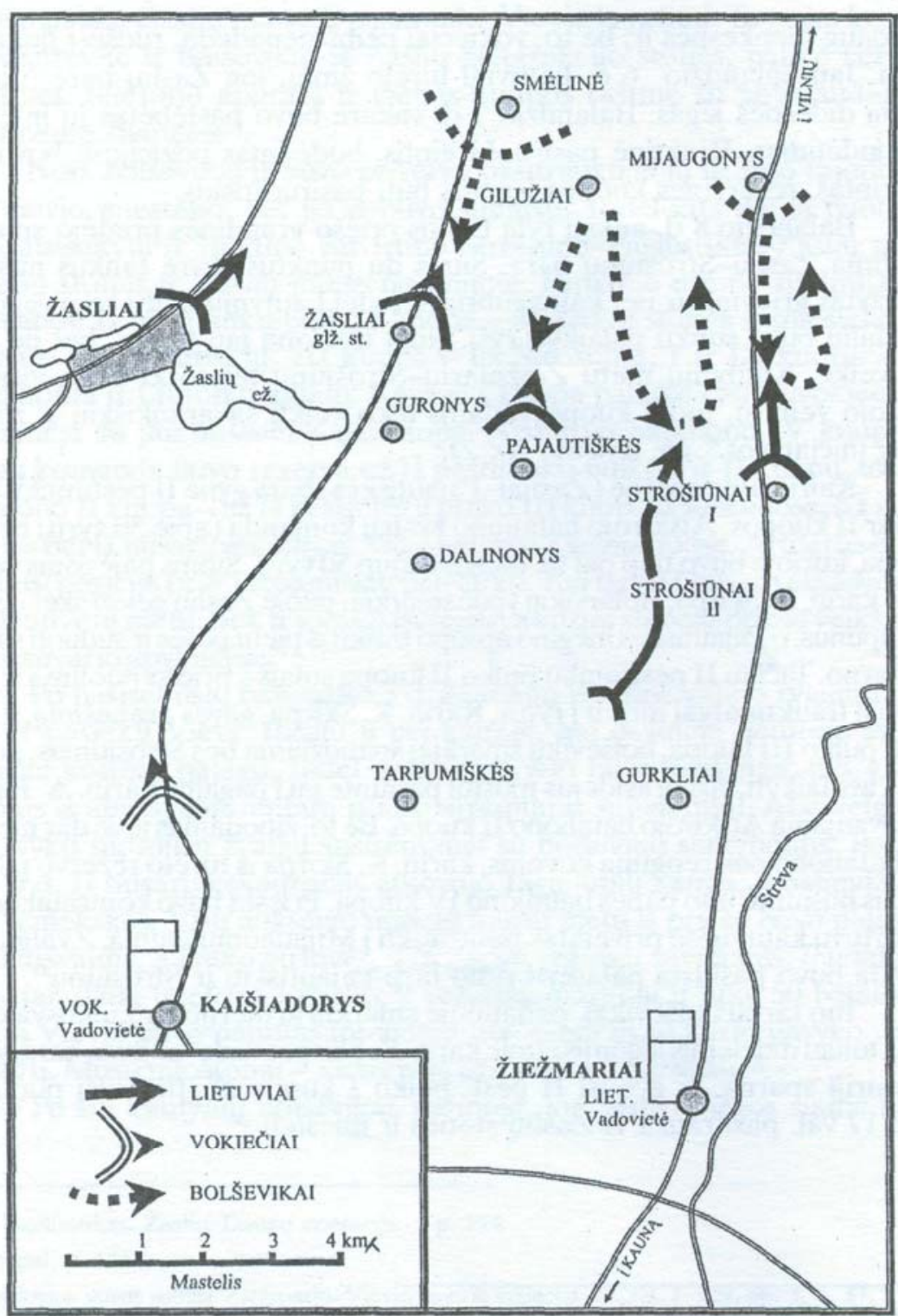

Schema Nr. 2

Žasliu kautynès $1919 \mathrm{~m}$. balandžio $8 \mathrm{~d}$. 
Pasitraukus I kuopai, susidare pavojus II kuopai, gynusiai Pajautiškes, nes kairysis sparnas tapo atviras ir bolševikai galejo apeiti iš sparno. Kairiajam sparnui apsaugoti dar buvo nusiųstas II kuopos vienas būrys, buvęs rezerve aukštumoje 150, tačiau jis bendros padeties jau nepataisé. Apie susidariusias aplilnkybes pranešus rinktinès vadui karin. J. Butkui, šis isakè atsitraukti į Žiežmarius. Apie 18 vai. $30 \mathrm{~min}$. II kuopa per Tarpumiškių dvarą atsitrauke i nurodytą vietą ${ }^{39}$.

Bolševikai nepasisekus Stošiūnų puolimui, artilerijos ir kulkosvaidžiu ugni sutelkè i Atskirojo bataliono II ir IV kuopu bara - kapines ir 115 aukštumą. Dalis jų, atsidūrę kairiajame baro sparne, iš miško ižambine ugnimi apšaude abi kuopas. Taigi bolševikai puolè frontu nuo Mijaugoniu kaimo ir iš sparno, t. y. iš miško. Nors priešo artilerijos sviediniai krisdavo maždaug už $1 \mathrm{~km}$ kuopų užnugaryje, tačiau tarpe menką patyrimą turinčių karių jie kèlė paniką. Todèl i kairiji sparną buvo pasiųsta sustiprinta žvalgyba, kuri priverte priešą iš šio sparno pasitraukt ${ }^{40}$.

Pačiame kautynių ikarštyje sugedo IV kuopos kulkosvaidis, o ir šovinių buvo likę jau nedaug. Neprityrę kulkosvaidininkai ilgai nesugebejjo jo sutaisyti ir tuo pasinaudoję bolševikai dar atkakliau veržèsi pirmyn. Tuo kritišku momentu visgi pavyko kulkosvaidi sutaisyti ir į artejjanti priešą buvo atidengta smarki ugnis, kuri bolševikams padare daug nuostolių. Buvo matyti, kaip bolševikai, jau lipantys per lauke buvusią tvora, krito nuo kulkosvaidžio ugnies. Daug ju buvo nukauta ir kuopu kariu taikliais šautuvų šūviais. Nuolat buvo girdèti II kuopos vado karin. A. Jakšto raginimai: „Vyrai, tik laikykit, vyrai laikykit!" Vietinių gyventoju pasakojimu, bolševikai iš to lauko nusivežè apie 80 nukautų ir sužeistu kareivių. Jų puolimas buvo sustabdytai ${ }^{41}$.

Nesitikedami išstumti lietuvių iš jų užimtu pozicijų iš priešakio, bolševikai mišku apejo IV kuopos kairiji sparną ir puolè iš šono. Ši jų manevrą lietuviai pastebejo ir smarkia ugnimi priverste juos pasitraukti Pajautiškių kryptimi. Tačiau apie 17 vai. bolševikai dar didesnèmis jègomis mėgino pakartoti savo manevra. Suspietus artilerijos ir kulkosvaidžiu ugni, bolševikai visiškai pakriko ir pasitrauke Mijaugonių kaimo kryptimi. Temstant kautynès aprimo.

\footnotetext{
${ }^{39}$ Ten pat, 1. 7.

${ }^{40}$ A. Vasiliauskas, Žasliu-Daugu operacija..., p. 200.

${ }^{41}$ A. V. Kautynės ties Žasliais ir Strošiūnais..., p. 442.
} 
Kautynèse ties Strošiūnais ypač pasižymèjo šie Atskirojo bataliono kariai: puskarininkiai Petras Daunoras, Juozas Pocius, Juozas Černiauskas, skyrininkas Domininkas Narbutas, eiliniai Aleksas Baušys, broliai Pranas ir Motiejus Kilikevičiai, Pranas Valkauskas, Andrius Makarevičius, Stasys Jakubauskas, Jonas Janušaitis, Petras Šimkus, Juozas Vaičaitis, Jonas Plioplys, Stasys Karpavičius ir kt. ${ }^{42}$

Visgi karinei vadovybei ịsitikinus tolesnio lietuviu puolimo prieš gausias bolševiku pajęgas neperspektyvumu, balandžio $8 \mathrm{~d}$. vakare buvo gautas rinktinès vado karin. J. Butkaus isakymas visoms kuopoms atsitraukti iki Gurkliu kaimo ${ }^{43}$. Po keleto dienu Atskirasis batalionas grižo i Kauną, o II pèstininku pulko I batalionas prieš Žiežmarius užèmè šias pozicijas: viena kuopa su 2 kulkosvaidžiais - ant aukštumos prie kelio i Remizava, kita kuopa su 2 kulkosvaidžiais - Gurklių dvare, III kuopa su 1 kulkosvaidžiu - Turlaviškių kaime, artilerijos baterija - prie Cegelnès. Vokiečių sargybos buvo išdèstytos Žiežmarių miestelio pakraščiuose prie kelio Remizavas-Vievis-Aukštadvaris ${ }^{44}$.

Kovų su bolševikais metu šiame bare žuvo 4, sužeista 40 ir dingo be žinios 20 kareivių ${ }^{45}$. Balandžio 10 d. Žiežmariuose įvyko iškilmingos žuvusių karių laidotuvès dalyvaujant didelei miniai aplinkiniu gyventojų. Jose taip pat dalyvavo Atskirosios brigados vadas karin. S. Nastopka su štabo ir daugybe kitu kariui ${ }^{46}$.

Atsiliepdama i bendras lietuvių kovas prie Daugų ir Žaslių Vilniaus kryptimi, Sovietų Rusijos vyriausybė priekaištavo Vokietijai, jog bolševikų kariuomenès dalys buvo puolamos su vokiečių karinių dalinių priedanga ir taip buvo pažeidžiama $1919 \mathrm{~m}$. sausio $18 \mathrm{~d}$. sutartimi tarp šių valstybių nustatyta demarkacijos linija. Nors, kaip jau minejjome anksčiau, vokiečiai faktiškai šios linijos laikèsi, tuo tarpu bolševikai ją dažnai pažeidinėjo. Vokietijos vyriausybe pageidavo, jog Lietuvos valdžia tinkamai išspręstų ši klausimą. Todèl Lietuvos vadovybè ir nutarè savo karinius

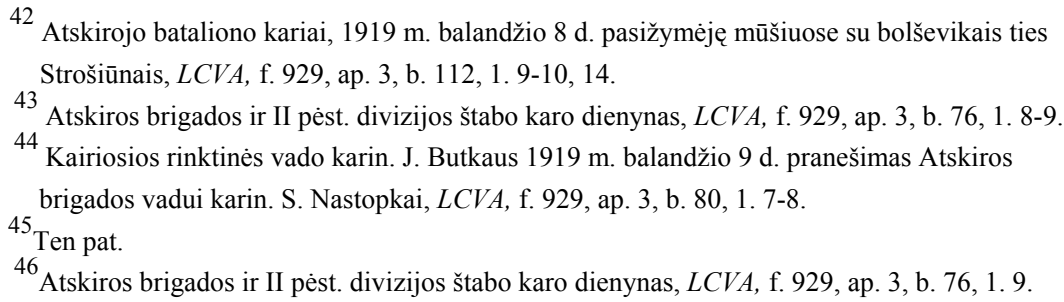


dalinius atitraukti. Balandžio 9-10 d. Strošiūnų-Pajautiškių-Žaslių miestelio ir geležinkelio stoties baras buvo perduotas vokiečiu apsaugai ${ }^{47}$. Šiais vadovybès veiksmais pirmoji planinga puolamoji karinè operacija Vilniui iš bolševikų vaduoti ir baigèsi.

\section{Išvados}

Vertinant pasirengimą minètai karinei operacijai, jos eigą ir rezultatus, reikia konstatuoti, jog:

1. Lietuvos kariuomenès vadovybè, turèdama šiame bare nepalyginamai menkesnes karines pajègas (3 labai silpnai parengtus batalionus prieš 5 bolševikų pulkus!), nutare suduoti priešui lemtingą smūgi, iš anksto suskaldydama jas i dvi nedideles skaičiumi rinktines, mažai paruoštas kariniu atžvilgiu bei prastai apginkluotas ir techniškai neaprūpintas, viena nuo kitos atitolusias apie $60 \mathrm{~km}$. Tokiomis sąlygomis jos negalëjo įvykdyti uždavinio - „pasistūmèti kiek galima pirmyn Vilniaus kryptimi".

2. Kovų metu nebuvo veiksmų suderinamumo nei tarp abiejų rinktinių, nei kiekvienos jų viduje. Jos net pati priešo puolimą pradejo skirtingu laiku.

3. Vertinant kautynes taktiniu požiūriu, reikia pažymėti, jog Kairiosios rinktinès vadas karin. J. Butkus net neišleido rinktinei i̇sakymo pulti. Tuo tarpu Dešiniosios rinktinès vadas karin. K. Ladyga, dar būdamas Alytuje, maždaug už $20 \mathrm{~km}$ nuo priešo pozicijų, nors ir parengè bei paskelbe issakymą, tačiau jame nebuvo atsižvelgta i bolševiku jėgų išsidèstymą vietoje, nepateikta vietovių specifika ir kt.

4. Pačių kautynių metu, keičiantis situacijai, abiejose rinktinèse nebuvo tinkamai iqvertintos tiek priešo, tiek ir savo jègu galimybès užimtu pozicijų atžvilgiu, neieškota silpnesniu priešo vietų, kuriomis būtų buvę galima pasinaudoti pranašumui igyti.

5. Rinktinių veiksmams labai neigiamai atsiliepé tai, kad nebuvo techniniu priemonių, visų pirma ryšių. O be jų tinkamai vadovauti karinèms operacijoms buvo neimanoma.

6. Pats Kairiosios rinktinès atsitraukimas iš fronto nebuvo planingas: kai kurios kuopos traukèsi tvarkingai, o kitos buvo paliktos likimo valiai ir tik dèl priešo neapdairumo nenukentejo.

${ }^{47}$ K Ališauskas, Siekiame atsiimti Vilnių..., p. 261. 
7. Lietuvos kariuomenès atsitraukimas iš fronto ir sąlyčio su bolševikais netekimas turejjo neigiamų padarinių lenkams $1919 \mathrm{~m}$. balandžio 19-21 d. puolant Vilnių. Lietuviai šioje kovoje negalèjo dalyvauti, ir bolševikai, pasinaudoję tokia padetimi, laisvai pasitraukè iš fronto į šiaurę, Maišiagalos kryptimi.

Ir vis dèlto negalime neivertinti vieno dalyko: nors šiose kautynèse ir nepasiseke sumušti priešo ir bent jau pasistumti Vilniaus kryptimi, tačiau čia buvo galutinai sugniuždytos bolševikų pastangos pro Alytų ir Kaišiadoris žygiuoti į Kauną, o po to užimti ir visą Lietuvą.

\section{Résumé \\ Tentative de reprendre Vilnius aux Bolcheviques au printemps 1919, Dr doc. Vytautas Lescius}

(Université de Vilnius)

Lors de l'analyse de la préparation de ces opérations militaires, de leur déroulement et de leur résultat, force est de constater que :

Le commandement de l'armée lituanienne, bien qu'ayant sur cette ligne de front des forces armées incomparablement moins nombreuses ( 3 bataillons insuffisamment préparés contre 5 régiments bolcheviques), a décidé de porter le coup décisif q l'ennemi en les divisant 3 l'avance en deux équipes aux effectifs réduits, mal préparées d'un point de vue militaire, avec des armes en mauvais état, non assistées techniquement et séparées de 60 kilomètres. Dans de telles conditions, il leur était impossible de réaliser leur objectif, « avancer le plus possible en direction de Vilnius ».

$\mathrm{Au}$ moment des combats il n'y avait aucune coordination des actions entre les deux équipes, et mzme au sein des équipes. L'attaque ennemie eut mzme lieu q des moments différents.

En analysant la bataille d'un point de vue tactique, il faut signaler que l'officier J. Butkus, chef de l'équipe de gauche, n'est mzme pas allé jusqu'3 donner l'ordre q son équipe d'attaquer. Dans le mzme temps, l'officier K. Ladyga, chef de l'équipe de droite, bien qu'étant encore 3 Alytus q 20 kilomètres des positions ennemies, a préparé et donné l'ordre, cependant il n'a pas pris en compte le positionnement des troupes 
bolcheviques, n'a pas précisé les particularités du terrain etc.

$\mathrm{Au}$ c ur de la bataille, la situation étant en train de prendre une autre tournure, les forces ennemies tout comme celles des équipes n'ont pas été, dans les deux équipes, estimées avec suffisamment de précisions par rapport aux positions occupées, le côté faible de l'ennemi ayant permis de prendre l'avantage n'a pas été recherché.

Les actions des deux équipes ont été empzchées par l'absence de moyens techniques, et plus particulièrement de transmission. Faute de ce dernier, il est impossible de diriger des opérations militaires comme il se doit.

Le retrait de l'équipe de gauche du front n'était pas prévu : quelques pelotons se sont retirés en ordre, d'autres ont été laissés 3 leur sort et furent victimes uniquement en raison du manque de prévoyance de l'ennemi.

Le retrait de l'armée lituanienne du front et la perte de contact avec les Bolcheviques eurent des conséquences négatives pour les Polonais lors de leur attaque contre Vilnius du 19 au 21 avril 1919. Les Lituaniens n'étant pas en mesure de participer 3 cette bataille, les Bolcheviques en tirant parti de cette situation, ont repoussé le front librement au nord dans la direction de Maisiagala.

Malgré tout il est impossible de ne pas attirer l'attention sur un seul aspect : mzme si pendant cette bataille il a été impossible de battre l'ennemi et de se rapprocher de Vilnius, c'est pourtant ici que furent anéantis les derniers efforts des Bolcheviques de marcher sur Kaunas en passant par Alytus et Kaisiadoris, pour occuper par la suite la Lituanie entière. 